\author{
Abstracta Iranica \\ Abstracta Iranica Revue bibliographique pour le domaine irano-aryen \\ Volume 37-38-39 | 2018 \\ Comptes rendus des publications de 2014-2016
}

\title{
Carlo G. Cereti, Gianfranco Terribili, Alessandro Tilia. "Paikuli in its Geographical Context"
}

\section{Alessia Zubani}

\section{(2) OpenEdition}

1 Journals

Édition électronique

URL : http://journals.openedition.org/abstractairanica/45939

DOI : 10.4000/abstractairanica.45939

ISBN : 1961-960X

ISSN : 1961-960X

Éditeur :

CNRS (UMR 7528 Mondes iraniens et indiens), Éditions de l'IFRI

Référence électronique

Alessia Zubani, «Carlo G. Cereti, Gianfranco Terribili, Alessandro Tilia. "Paikuli in its Geographical Context" », Abstracta Iranica [En ligne], Volume 37-38-39 | 2018, document 30, mis en ligne le 30 décembre 2018, consulté le 26 septembre 2020. URL : http://journals.openedition.org/ abstractairanica/45939; DOI : https://doi.org/10.4000/abstractairanica.45939

Ce document a été généré automatiquement le 26 septembre 2020

Tous droits réservés 


\title{
Carlo G. Cereti, Gianfranco Terribili, Alessandro Tilia. "Paikuli in its Geographical Context"
}

\author{
Alessia Zubani
}

\section{RÉFÉRENCE}

Carlo G. Cereti, Gianfranco Terribili, Alessandro Tilia. "Paikuli in its Geographical Context" in A. Krasnowolska, R. Rusek-Kowalska (eds.). Studies on the Iranian World: Before Islam. Proceedings ofthe 7th European Conference of Iranian Studies (Crakow 2011). Krakow: Jagellonian University Press, 2015, p. 267-278.

1 Cette étude topographique offre une contribution à l'étude de la géographie administrative et commerciale sassanide, en prenant en considération le site monumental de Pāikūlī et le territoire où le roi Narseh (293-302) en ordonna la construction. À travers des sources hétérogènes étudiées dans le cadre d'une mission italo-kurde (initiée en 2006) conduite dans une région comprenant les provinces de Dahūk, Erbil et Sulaymānīyah, les A. décrivent le col de Pāikūlī - et, en général, la région de Sulaymānīyah - comme point central d'un réseau routier d'époque sassanide, situé entre les régions occidentales - et la capitale Ctésiphon -, et le plateau iranien. Assurant ainsi la cohésion de l'Empire, ce réseau permettait aussi le déplacement de groupes nombreux (commerçants, militaires etc.). 


\section{AUTEURS}

\section{ALESSIA ZUBANI}

Doctorante EPHE, Mondes iranien et indien, Paris 